\title{
Review
}

\section{Immunochemistry of pathogenic yeast, Candida species, focusing on mannan}

\author{
By Nobuyuki ShIBAta, ${ }^{* 1}$ Hidemitsu KobayASHI ${ }^{* 2}$ and Shigeo SuzUKI ${ }^{* 3, * 4, \dagger}$ \\ (Communicated by Takao SEKIYA, M.J.A.)
}

\begin{abstract}
This review describes recent findings based on structural and immunochemical analyses of the cell wall mannan of Candida albicans, and other medically important Candida species. Mannan has been shown to consist of $\alpha-1,2-, \alpha-1,3-, \alpha-1,6-$, and $\beta-1,2$-linked mannopyranose units with few phosphate groups. Each Candida species has a unique mannan structure biosynthesized by sequential collaboration between species-specific mannosyltransferases. In particular, the $\beta$-1,2-linked mannose units have been shown to comprise a characteristic oligomannosyl side chain that is strongly antigenic. For these pathogenic Candida species, cellsurface mannan was also found to participate in the adhesion to the epithelial cells, recognition by innate immune receptors and development of pathogenicity. Therefore, clarification of the precise chemical structure of Candida mannan is indispensable for understanding the mechanism of pathogenicity, and for development of new antifungal drugs and immunotherapeutic procedures.
\end{abstract}

Keywords: Candida, mannan, ${ }^{1} \mathrm{H}$ NMR, mannosyltransferase, pathogenicity, Dectin-2

\section{Introduction}

Candida species causes a variety of infections ranging from superficial candidiasis to life-threatening invasive candidiasis, also known as disseminated or systemic candidiasis. Predisposing factors for candidiasis include: immunosuppression, broadspectrum antibiotics, and cytotoxic therapies; the presence of intravenous catheters; diabetes; neutropenia; very low birth weights and AIDS. ${ }^{1)}$ Invasive candidiasis is on the rise with the increasing population of susceptible individuals, while treatment is hampered by antifungal resistance. Thus, Candida species have now become the third most prevalent cause of bloodstream infections. Candida

*1 Department of Infection and Host Defense, Tohoku Pharmaceutical University, Miyagi, Japan.

*2 Department of Microbiology, Nagasaki International University, Nagasaki, Japan.

*3 Professor Emeritus, Tohoku Pharmaceutical University, Miyagi, Japan.

*4 Sendai Research Institute for Mycology, Miyagi, Japan.

$\dagger$ Correspondence should be addressed: S. Suzuki, 1-14-34 Toshogu, Aoba-ku, Sendai, Miyagi 981-0908, Japan (e-mail: suzusige@seagreen.ocn.ne.jp). idylamino.

Abbreviations: ManTase: mannosyltransferase; PA: pyr-

doi: $10.2183 /$ pjab. 88.250

(C)2012 The Japan Academy pathogenicity also depends on hypothetical virulence factors. These include the production of secreted hydrolytic enzymes, dimorphic transition from yeast to mycelium, antigenic variability, phenotype switching, adhesion to host cells, and cell-surface hydrophobicity.

The outermost layer of the cell wall plays an essential role in host interaction, including the triggering and modulation of the anti-Candida host immune responses, which appear to rely on the interplay between the innate and adaptive immunities. For this reasons, the cell wall of Candida species has been the focus of attention. The outer layer of the cell wall of Candida species consists of mannoproteins containing O-glycosylated oligosaccharide and Nglycosylated polysaccharide moieties. Both carbohydrate moieties have been shown to be important in host-fungal interactions and virulence. The N-glycosylated polysaccharide, mannan, has a comb-like structure with an $\alpha$-1,6-linked backbone moiety and many oligomannosyl side chains with a low number of phosphate groups. Some oligosaccharides are connected to a phosphate group by a phosphodiester bond. Phosphate-bound oligosaccharides can be selectively released from mannan by treatment with a weak acid solution, such as $10 \mathrm{mM} \mathrm{HCl}$ at $100^{\circ} \mathrm{C}$ for 

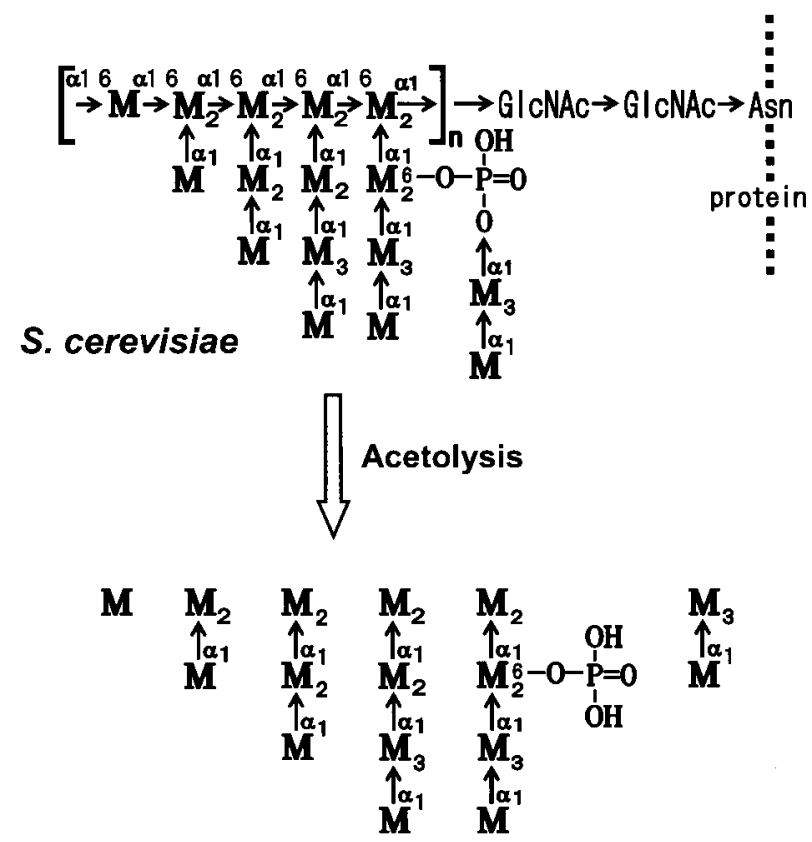

Fig. 1. Structure of the cell-wall mannan of S. cerevisiae. M denotes an $\alpha$-D-mannopyranose unit. The acetolysis cleaves the $\alpha$-1,6-linkage of the mannan to produce side chain oligosaccharides.

1h. Mannan can thus be fragmented by acetolysis, which selectively cleaves the backbone $\alpha$-1,6-linked mannose units (Fig. 1). The chemical structure of the resultant mannooligosaccharides that originate from the side chains have been analyzed by methylation, and ${ }^{1} \mathrm{H}$ and ${ }^{13} \mathrm{CNMR}$, and the antigenic properties studied by inhibition assays in mannan-anti-mannan antibody systems. Mannan displays strong antigenicity, dominating the humoral antibody response, and is also recognized by the innate immune system. Therefore, determination of the chemical structure of mannan of medically important pathogenic Candida species is indispensable in order to elucidate the biodefense mechanisms of hosts as well as for identifying the mechanisms of pathogenicity.

\section{Structural and serological studies of Candida mannan in early stage}

Comprehensive antigenic analyses of the genus Candida were first carried out by Tsuchiya et al. ${ }^{2)-4)}$ and Fukazawa et al. ${ }^{5)}$ on C. albicans, C. tropicalis, C. stellatoidea, C. parapsilosis, C. guilliermondii, C. glabrata, C. krusei, and C. kefyr. All of the reciprocally adsorbed antisera were examined by a slide agglutination test and the antigenic formulas were then formulated. Hasenclever and Mitchell ${ }^{6)}$ proposed that the C. albicans species could be divided into two serotypes, A and B. Later, Summers et $a l .{ }^{7)}$ showed that the chemical entity of the major antigen of the genus Candida was a cell wall polysaccharide, mannan. Gorin and Spencer ${ }^{8)}$ extracted mannose-containing polysaccharides from hundreds of species of fungi and analyzed them by ${ }^{1} \mathrm{H}$ NMR. A $\beta$-1,2-linkage containing mannan was first reported by Gorin et al. ${ }^{9)}$ in Pichia pastoris and Citeromyces matritensis. We demonstrated the usefulness of the precipitin-inhibition assay using mannooligosaccharides obtained from mannan by acetolysis for the structural identification of epitopes, ${ }^{10), 11)}$ and found that mannohexaoses, Man $\alpha 1-2 M a n \alpha 1-2 M a n \alpha 1-2 M a n \alpha 1-2 M a n \alpha 1-2 M a n$ and Man $\alpha 1-3$ Man $\alpha 1-2 M a n \alpha 1-2 M a n \alpha 1-2 M a n \alpha 1-$ 2Man, are the strongest epitopes for the C. albicans serotype $A^{12)}$ and $B$ mannan. ${ }^{13)}$ Suzuki and Fukazawa $^{14)}$ also showed the antigenicity of the mannohexaose, Man $\alpha 1-3$ Man $\alpha 1-2$ Man $\alpha 1-2 M a n \alpha 1-$ 2Mano1-2Man, in C. albicans serotype A mannan. Funayama et al. ${ }^{15), 16)}$ reported the presence of a mannohexaose side chain, Man $\alpha 1-2$ Man $\alpha 1-3$ Man $\alpha 1-$ 2Mano1-2Man 1 1-2Man, in C. albicans serotype B and C. parapsilosis mannan. The presence of structural and immunochemical heterogeneity in mannan was shown by Okubo et al. ${ }^{17), 18)}$ using stepwise anion exchange chromatography. They showed that the reactivity of mannan subfractions against antimannan serum correlates well with the amount of phosphate groups and phosphodiesterified oligosaccharides. The structure of antigenic factors of mannan in medically important Candida species have been described elsewhere. ${ }^{19)-21)}$ It is noteworthy that the use of high-resolution NMR spectroscopy made possible great advances in the immunochemistry of Candida mannan.

\section{3. $\beta$-1,2-Linked mannooligosaccharides connected via a phosphate group of the mannan side chain}

Mannan of $S$. cerevisiae contains $\alpha$-1,3-linked mannobiose bound through phosphate groups in the side chain. ${ }^{22)}$ However, we found that $\beta$-1,2-linked oligomannosyl units up to heptaose, $\operatorname{Man} \beta 1-2 \operatorname{Man} \beta 1$ $2 \operatorname{Man} \beta 1-2 \operatorname{Man} \beta 1-2 \operatorname{Man} \beta 1-2 \operatorname{Man} \beta 1-2 M a n$, exist in the antigenic mannan of $C$. albicans in an acid-labile phosphodiesterified form. ${ }^{23), 24)}$ The $\beta$-1,2-linked mannooligosaccharide moieties were found to display stronger antigenicity than the $\alpha$-linked ones in the humoral antibody response of mammals, ${ }^{25)}$ corresponding to antigenic epitope, factor $5{ }^{26)}$ 

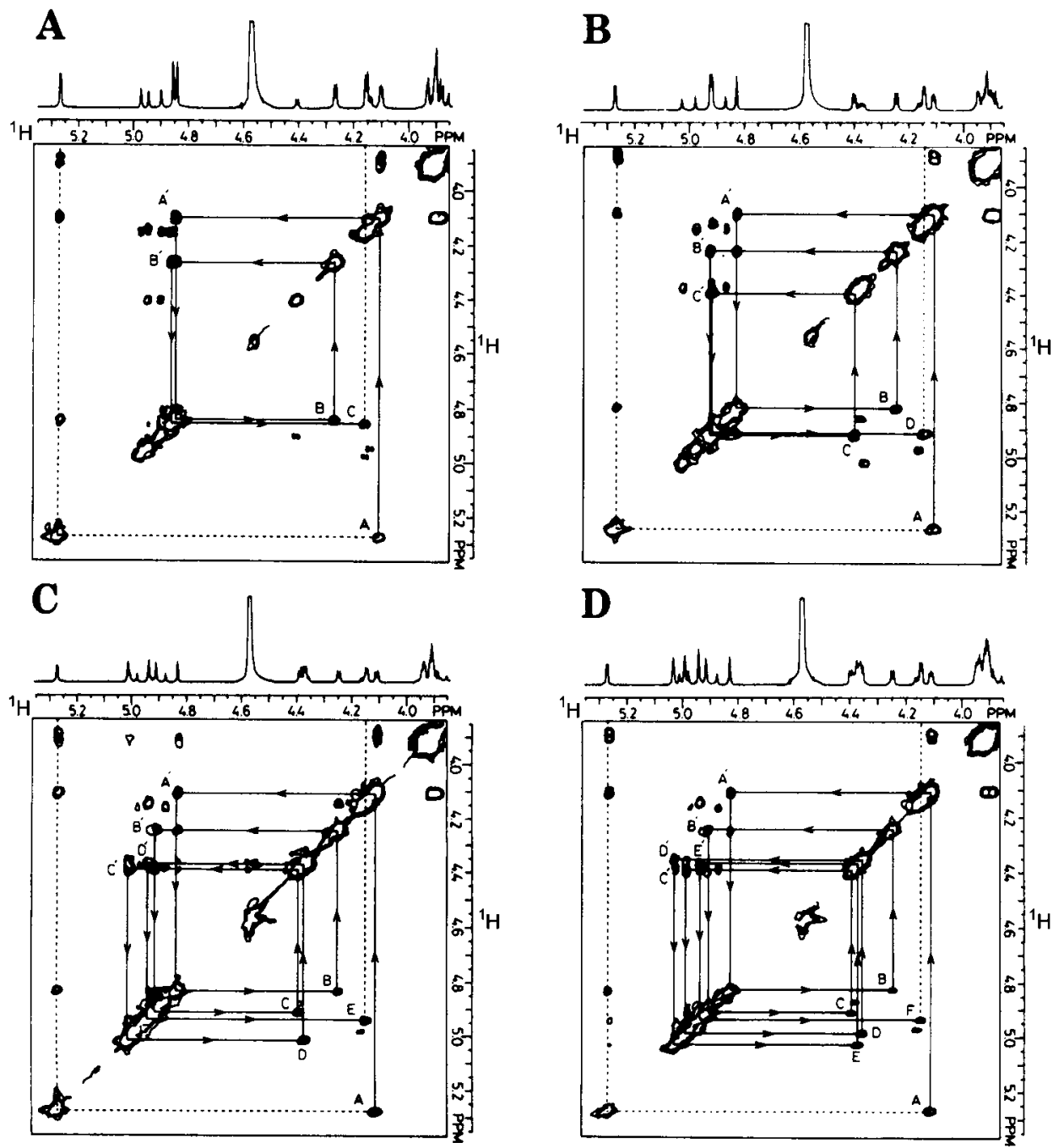

Fig. 2. Sequential H-1-H-2' connectivities of mannose units of the $\beta-1,2$-linked mannooligosaccharide (Ref. 27). (A) Mannotriose; (B) Mannotetraose; (C) Mannopentaose; (D) Mannohexaose. The right side of the diagonal shows COSY, and the left side of the diagonal shows NOESY. Primed letters indicate inter-unit H-1-H-2' NOE cross-peaks and unprimed letters, the H-1-H-2-correlated cross-peaks due to $J$-coupling. Arrows indicate the direction of the sequential connectivity from the reducing terminal unit to the nonreducing terminal unit.

The H-1 and H-2 signals of the $\beta-1,2$-linked mannooligosaccharides isolated by mild acid hydrolysis were assigned by a sequential NMR method that combines two-dimensional (2D) ${ }^{1} \mathrm{H}-{ }^{1} \mathrm{H}$ correlated spectroscopy (COSY) and 2D nuclear Overhauser effect (NOE) spectroscopy (NOESY) (Fig. 2). ${ }^{27)}$ The results indicate that $\mathrm{H}-1$ and $\mathrm{H}-2$ of each $\beta$-1,2-linked mannose unit show significantly different signals compared to those of the $\alpha$-linked units (Fig. 3). Reduction of the reducing terminal of these oligosaccharides by $\mathrm{NaBH}_{4}$ causes a significant downfield shift in the H-1 signals for the second and third mannose units, and an upfield shift for the fourth mannose unit. This result indicated that the influence of reducing terminal mannose unit reaches as far as the fourth mannose unit from the reducing terminal. The unprecedented shift effect of the H-1 signal suggests a folded conformation. We further assigned all of the ${ }^{1} \mathrm{H}$ and ${ }^{13} \mathrm{C}$ signals in each oligosaccharide. $^{28)}$ Poulain and coworkers ${ }^{29), 30)}$ made the same assignments. Nitz et al. ${ }^{31)}$ analyzed the solution conformation of the synthetic $\beta$-propyl glycoside derivatives of the $\beta$-1,2-linked mannooligosaccharide and detected many inter-unit NOEs between the $\mathrm{n}$ and $\mathrm{n}+3$ units. They also performed a simulated annealing from $500 \mathrm{~K}$ high temperature-molecular 


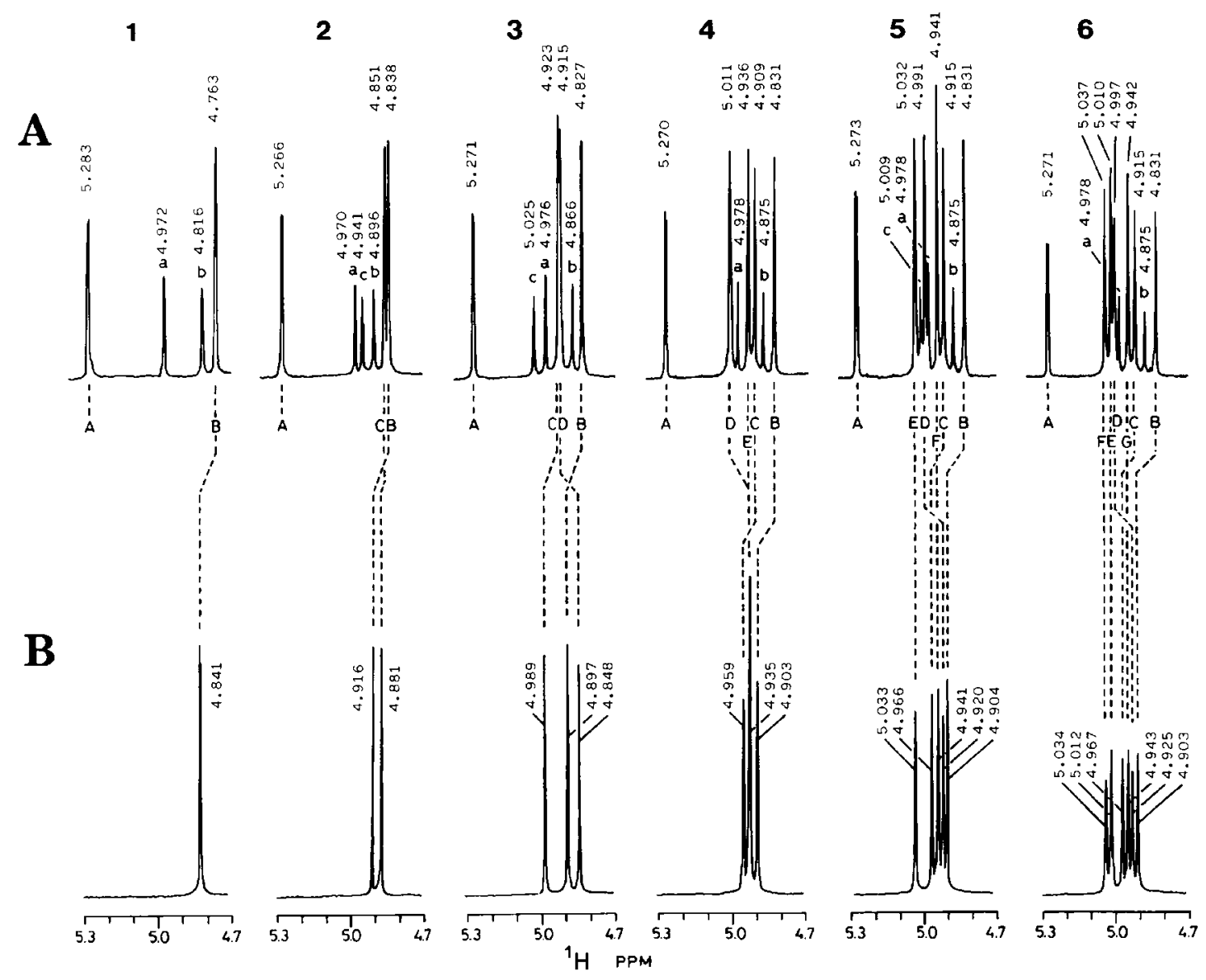

Fig. 3. ${ }^{1} \mathrm{H}$ NMR spectra of the $\beta$-1,2-linked mannooligosaccharides (A) and their corresponding alcohols (B) (Ref. 27). (1) Mannobiose; (2) Mannotriose; (3) Mannotetraose; (4) Mannopentaose; (5) Mannohexaose; (6) Mannoheptaose. The capital letters from A to G and the small letters from a to $\mathrm{c}$ refer to the mannose units from the reducing terminal $\alpha$-anomer unit and $\beta$-anomer unit of each oligosaccharide, respectively.

dynamics. The generated random energy structures were separately cooled to $5 \mathrm{~K}$, and then minimized. Based on the results, they concluded that the conformation is a compact helical structure with a three-unit repeat. We also analyzed the conformation of the free $\beta$-1,2-linked mannooligosaccharides and confirmed the compact helical conformation as shown in Fig. 4. ${ }^{32)}$

\section{4. $\beta$-1,2-Linked mannose units directly connected to the mannan side chain}

The side chain of the cell wall mannan from C. albicans serotype A strain was fragmented by acetolysis ${ }^{33)}$ under mild conditions, ${ }^{34)}$ and separated by Bio-Gel P-2 column chromatography or by highperformance liquid chromatography (HPLC). Although $\alpha$-mannosidase treatment of the acetolysis product of the C. albicans serotype B mannan com- pletely hydrolyzed it to mannose, that of the serotype A mannan retained a large amount of the longer oligosaccharides, from pentaose to octaose. ${ }^{35)-38)}$ These oligosaccharides consisted of one to four $\beta$ 1,2-linked mannose units connected to the $\alpha-1,2-$ linked mannotetraose, $\operatorname{Man} \beta 1-[2 \operatorname{Man} \beta 1]_{\mathrm{n}}-2 \mathrm{Man} \alpha 1-$ 2Man $\alpha 1-2$ Man $\alpha 1-2$ Man $(\mathrm{n}=0$ to 3$)$, and corresponded to the serotype A-specific antigen, factor 6. ${ }^{39)} \mathrm{We}$ also determined the structure of mannan in the medically important Candida species, $C$. tropicalis, ${ }^{40)}$ C. lusitaniae, ${ }^{41)}$ and C. glabrata, ${ }^{42)}$ and confirmed the presence of the factor 6 structure. Furthermore, we found that some Candida species, C. guilliermondii ${ }^{43)}$ and C. saitoana ${ }^{44)}$ also contain $\beta$-1,2-linked mannose units. However, the $\beta-1,2-$ linked mannose units in these Candida mannan were connected to the $\alpha$-1,3-linked mannose units of the side chain. We also found that the side chain 


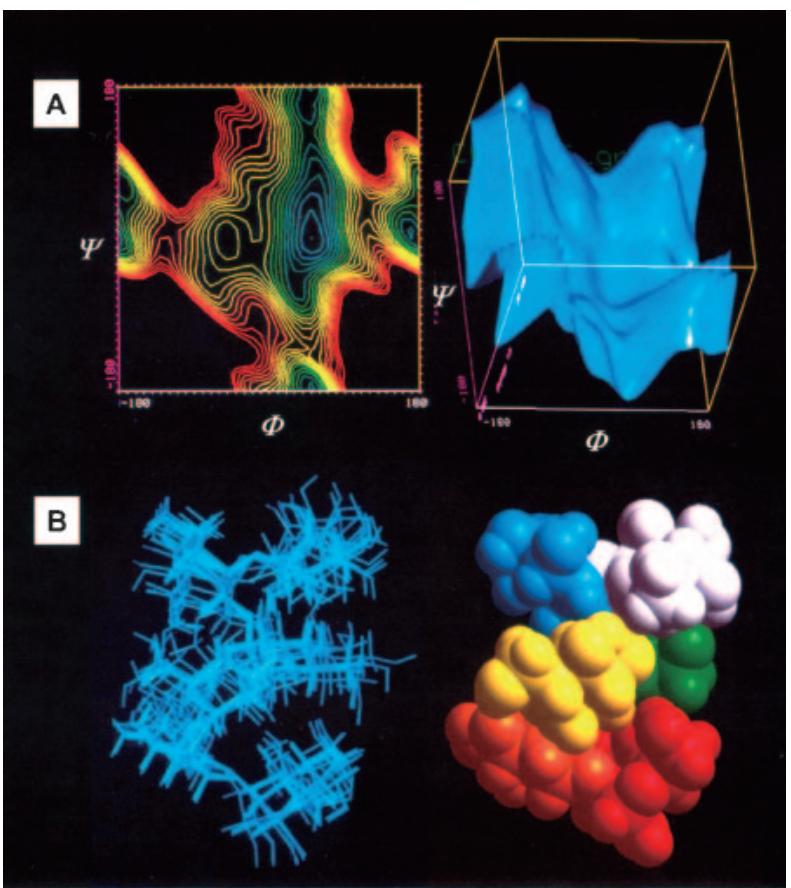

Fig. 4. Conformation analysis of the $\beta-1,2$-linked mannooligosaccharides. (A) Relaxed-residue steric energy map of the $\beta-1,2$ linked mannobiose as a function of the $\Phi\left(\mathrm{H}-1-\mathrm{C}-1-\mathrm{O}-1-\mathrm{C}-2^{\prime}\right)$ and $\Psi$ (C-1-O-1-C-2'-H-2') torsion angles. (B) Lowest energy conformers of the $\beta$-1,2-linked mannohexaose obtained by simulated annealing from $900 \mathrm{~K}$ molecular dynamics. oligosaccharide contains the $\alpha$-1,6-linked branching mannose unit. This side chain oligosaccharide, Man 31 -2Manß1-2Man $\alpha 1-3(\operatorname{Man} \alpha 1-6)$ Man $\alpha 1-2 M a n \alpha 1-$ 2Man, displays different antigenicity from the factor 6 , and corresponds to factor 9. As shown in Fig. 5, these Candida species were found to contain species-specific mannan structures.

\section{Additivity rule for the ${ }^{1} \mathrm{H}$ NMR signals of mannose units in Candida mannan}

We found an additivity rule for the $\beta$-1,2-linked mannose unit. $^{38)}$ Figure $6 \mathrm{~A}$ shows the $2 \mathrm{D}$ total correlation spectroscopy (TOCSY) spectrum of the C. albicans serotype A mannan. The shifts in the $\mathrm{H}-$ 1-H-2-correlated cross-peaks caused by the addition of the $\alpha$-1,2-linked mannose unit and the $\beta$-1,2-linked mannose unit are shown by the solid arrows and the dashed arrows, respectively. The shift caused by the addition of the $\beta$-1,2-linked mannose unit was significantly different from that caused by the addition of the $\alpha$-1,2-linked mannose unit. The addition of the $\beta$-1,2-linked mannose unit to the nonreducing terminal $\alpha$-1,2-linked mannose unit of the side chain caused a downfield shift of the latter's cross-peak from 10 to 15 . Similar shifts were also observed for the cross-peak of the nonreducing terminal $\alpha$-1,3-linked mannose unit from 7 to 13 .
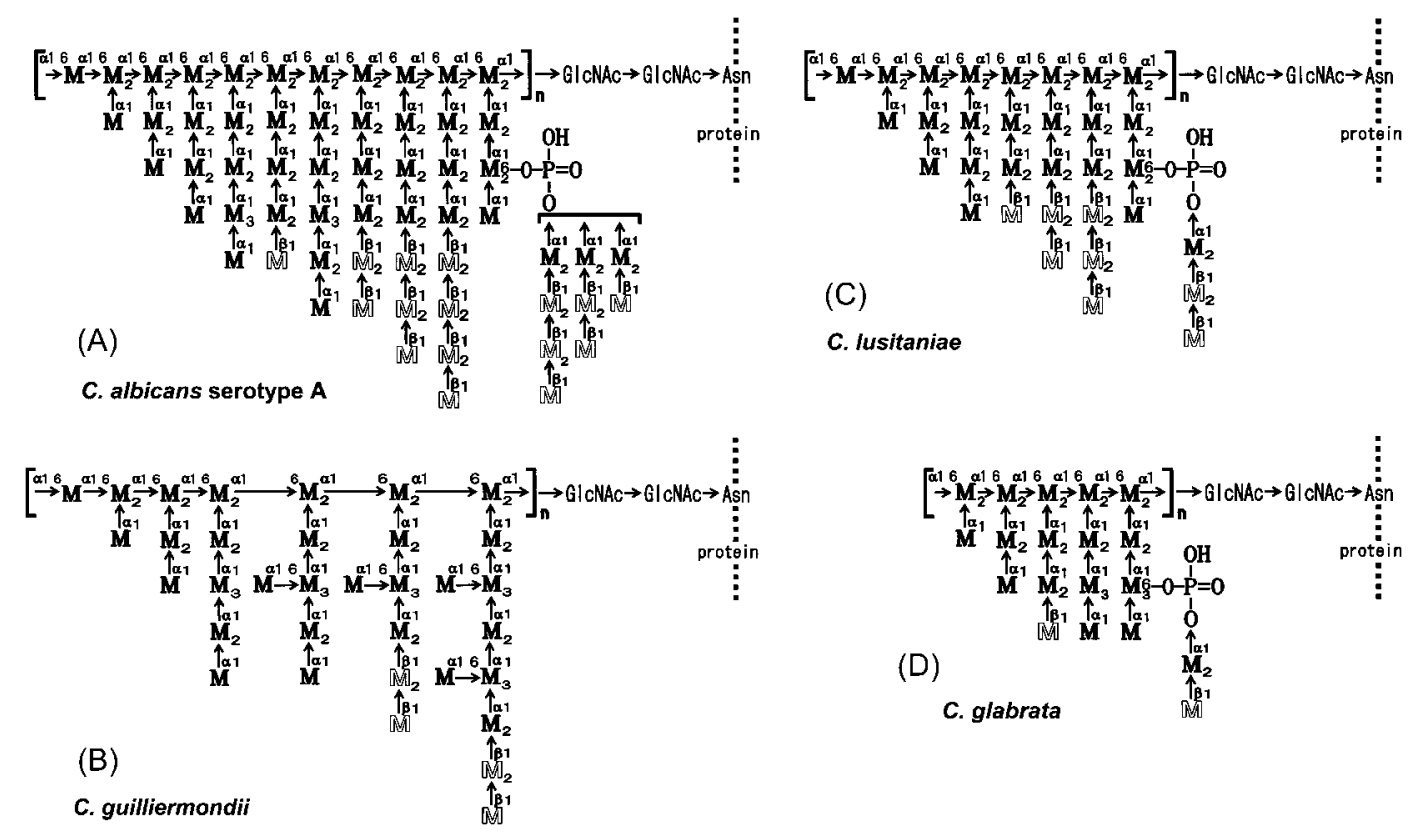

Fig. 5. Structure of the cell wall mannan of Candida species. (A) C. albicans serotype A, (B) C. guilliermondii, (C) C. lusitaniae,

(D) C. glabrata. M set in outlined type indicates $\beta$-D-mannopyranose unit. These mannan contain the $\beta$-1,2-linked mannose units at the nonreducing terminal side of the side chains as well as at the phosphodiesterified oligosaccharide moiety. 
A
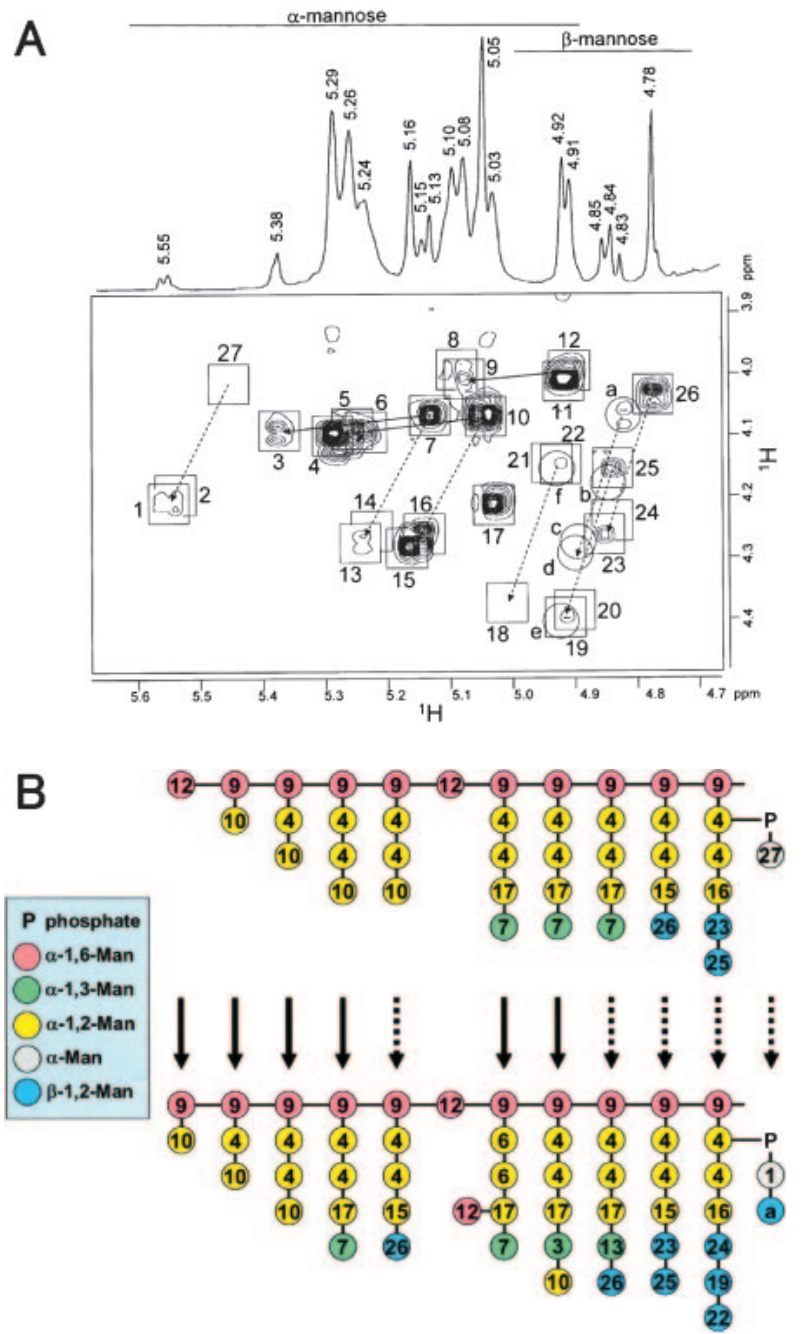

Fig. 6. Additivity rule of the ${ }^{1} \mathrm{H}-\mathrm{NMR}$ chemical shift for mannose units. (A) TOCSY spectrum of the mannan of C. albicans serotype A (Ref. 38). The boxed regions in the spectrum indicate the $\mathrm{H}-1-\mathrm{H}-2$-correlated cross-peaks of the $\alpha$ - and $\beta$-mannose units in the acid-stable polysaccharide moiety. The circled crosspeaks correspond to the $\beta$-1,2-linked mannose units of the phosphodiesterified acid-labile oligosaccharide side chains. The broken- and continuous-line arrows indicate the shifts in the cross-peaks caused by the addition of $\beta$-1,2-linked mannose units and $\alpha$-1,2-linked mannose units, respectively. (B) Structura diagram of the mannose units in the mannan and the shift effect of the cross-peaks caused by the addition of mannose units. The numbers on the mannose units correspond to the cross-peaks in panel A.

Figure $6 \mathrm{~B}$ illustrates the shift effect of the crosspeaks of the side chain mannose units by the addition of an $\alpha$ - or $\beta$-mannose unit observed in the TOCSY spectrum of Fig. $6 \mathrm{~A}$. These shifts were also found on the nonreducing terminal $\beta$-mannose units of the side chains. Cross-peaks 25 and 26, corresponding to the nonreducing terminal $\beta$-1,2-linked mannose units of the serotype A-specific side chain oligosaccharides, caused a downfield shift to 19 and 23, respectively, by the addition of a further $\beta$-1,2-linked mannose unit.

\section{The presence of branched side chains in mannan}

Although the presence of a branching structure in Candida mannan has been suggested ${ }^{5), 14), 45), 46)}$ the branched oligosaccharide has not been identified. We demonstrated the presence of the 3,6-branched hexaose side chain in the mannan of $C$. albicans serotype $\mathrm{B}$ by acetolysis under mild conditions, followed by methylation and ${ }^{1} \mathrm{H} \mathrm{NMR}$ analyses, and proposed the chemical structure shown in Fig. $7 .{ }^{47}$ ) The ${ }^{1} \mathrm{HNMR}$ signal of the 3,6-branched hexaose showed a characteristic upfield chemical shift on its $\alpha$-1,2-linked mannose unit. A steric effect of the $\alpha$ 1,6-linked branching mannose unit is causative of the shift of the cross-peak. The $C$. stellatoidea mannan was also found to contain 3,6-branched side chains. ${ }^{48)}$ On the other hand, the side chains of the mannan of C. parapsilosis consist of linear oligosaccharides. ${ }^{47}$ ) The presence of an $\alpha$-1,6-branched mannose unit in the yeast mannan was first determined in the Olinked oligosaccharide ${ }^{49)}$ of the mannan of Saccharomyces kluyveri, and later in the N-linked mannan moiety. ${ }^{50)}$

\section{Substrate specificity of mannosyltransferases of Candida species}

As substrate for the mannosyltransferase (ManTase) assay, mannooligosaccharides were connected to 2-aminopyridine to produce pyridylamino (PA)-derivatives. Using the PA-oligosaccharides as substrate, we assayed ManTase activity in the enzyme fraction of Candida cells in the presence of GDP-mannose. The enzyme reaction products were detected by HPLC equipped with a fluorescence spectrometer. To assess the substrate specificity of $\alpha$-1,6-ManTase of the C. albicans serotype B, the PA-derivatives of the several acceptor oligosaccharides prepared from the mannan of C. albicans, C. parapsilosis, C. guilliermondii, C. krusei, and $S$. cerevisiae were tested. The result indicates that the oligosaccharides containing $\alpha$-1,3-linked mannose units at the non-reducing terminal can serve as acceptors for $\alpha$-1,6-ManTase. ${ }^{51)}$ The C. albicans serotype A-specific oligosaccharide side chain is biosynthesized by the transfer of the first $\beta-1,2-$ linked mannose unit to the $\alpha$-1,2-linked manno- 


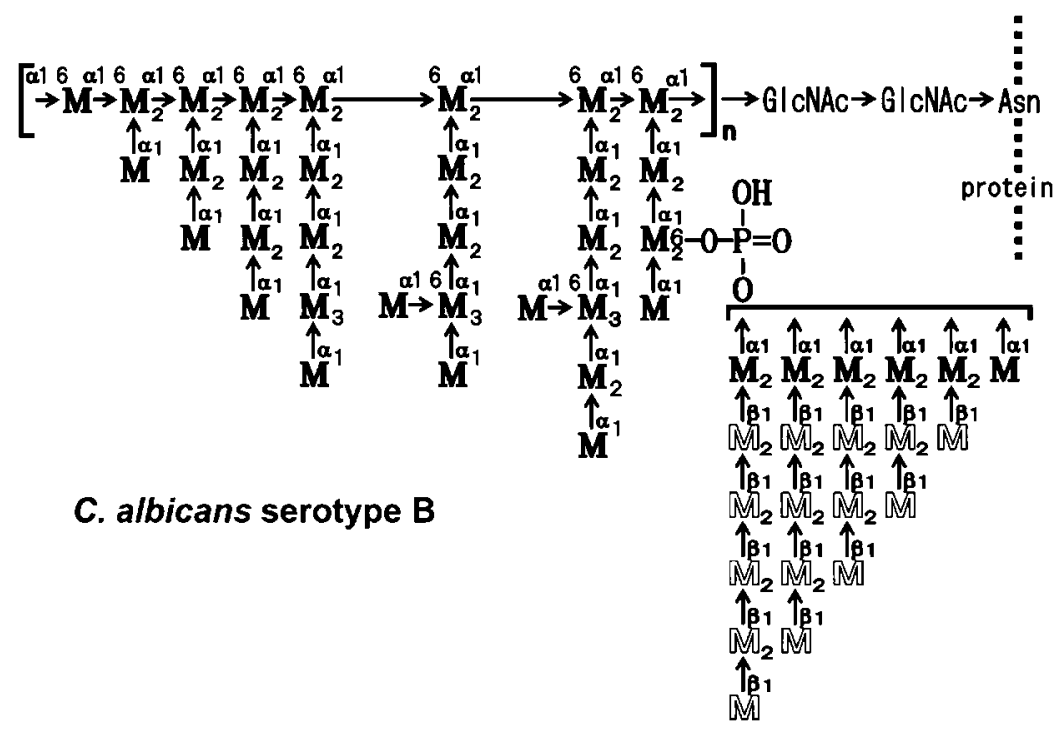

Fig. 7. Structure of the cell wall mannan of C. albicans serotype B. This mannan contains 3,6-branched mannose units at the side chains. $\beta-1,2$-linked mannose units are present only on the phosphodiesterified oligosaccharide moiety.

tetraose side chain by $\beta-1,2-$ ManTase I to produce Man $\beta 1-2 M a n \alpha 1-2 M a n \alpha 1-2 M a n \alpha 1-2 M a n$. Next, the second $\beta-1,2$-linked mannose unit is transferred by $\beta$ 1,2-ManTase II to produce Man $\beta 1-2 \mathrm{Man} \beta 1-2 \mathrm{Man} \alpha 1$ 2Mano1-2Man $\alpha 1-2$ Man. To assess the substrate specificity of $\beta-1,2$-ManTase II in the C. albicans serotype A cells, several PA-oligosaccharides prepared from mannan of C. albicans, S. kluyveri, and $P$. pastoris were tested. This result indicates that the enzyme requires not only the non-reducing terminal $\beta$-1,2-linked mannose unit, but also a penultimate $\alpha-1,2$ - or $\alpha-1,3$-linked mannose unit as substrate (Table 1). ${ }^{52)}$ In other words, the minimum structural requirement of $\beta-1,2$-ManTase II is $\operatorname{Man} \beta 1$ 2 Man $\alpha 1$-. Surprisingly, $\beta$-1,2-ManTase II activity was detected in the cells of C. albicans serotype B and C. stellatoidea strains, even though their mannan does not contain the serotype A-specific epitopes. To detect $\beta-1,2$-ManTase I in C. albicans, several $\alpha$-1,2-linked mannooligosaccharide PA-derivatives were tested. However, no activity was detected. This result suggests that the enzyme recognizes the side chain length extending from the backbone $\alpha-1,6-$ linked mannose unit, and therefore requires the oligosaccharide-containing $\alpha$-1,6-linked mannose unit as substrate. Although C. albicans mannan also contains $\alpha$-1,2-linked mannobiose and mannotriose side chains, the $\beta$-1,2-linked mannose unit is transferred only to the $\alpha$-1,2-linked mannotetraose side chain. On the other hand, in the case of $C$. lusitaniae $^{41)}$ and Citeromyces matritensis ${ }^{53)}$ mannan, $\beta$-1,2-linked mannose units are transferred only to the $\alpha-1,2$-linked mannotriose and mannobiose side chains, respectively (Fig. 8). These structural differences in the species support the above hypothesis. On the other hand, C. guilliermondii mannan contains $\beta$-1,2-linked mannose units bound to $\alpha-1,3-$ linked mannose units. ${ }^{43}$ ) Therefore, we tested the substrate specificity of $\beta-1,2$-ManTase I in C. guilliermondii cells. However, as shown in Table 1, linear oligosaccharides, which contain the non-reducing terminal $\alpha$-1,3-linked mannose unit, do not serve as acceptors. Therefore, we enzymatically synthesized several 3,6-branch-containing oligosaccharides, Man $\alpha 1-3($ Man $\alpha 1-6)$ Man $\alpha 1-2$ Man $\alpha 1-$, by using $\alpha$ 1,6-ManTase of C. albicans serotype B cells with oligosaccharides from C. albicans, C. krusei, and S. cerevisiae. The results indicate that these 3,6branched oligosaccharides are good acceptors. ${ }^{54)} \mathrm{We}$ further performed large-scale enzymatic modification of the C. albicans serotype B mannan, which does not contain the $\beta$-1,2-linked mannose unit in its side chains, but the 3,6-branched structure, Man $\alpha 1$ 3(Man 1 1-6)Man 1 1-. The incorporation of $\beta-1,2-$ linked mannose units into mannan using the transferase of $C$. guilliermondii was confirmed by the appearance of $\beta$-1,2-linked mannose-specific crosspeaks in the TOCSY.

Mille et al. ${ }^{55)}$ cloned and characterized a novel $\beta-1,2$-ManTase gene family in P. pastoris and $C$. albicans. They first performed a BLAST search of a $P$. pastoris genome sequence, for ManTase, using the 
Table 1. Substrate specificity of the mannosyltransferase activity in the enzyme fraction from Candida species

\begin{tabular}{|c|c|c|}
\hline \multirow{3}{*}{ Substrate $(5 \mathrm{mM})$} & \multicolumn{2}{|c|}{ Mannose incorporated $(\mathrm{nmol} / \mathrm{mg}$ protein $/ \mathrm{h})$} \\
\hline & \multicolumn{2}{|c|}{ C. albicans serotype A } \\
\hline & \multicolumn{2}{|c|}{$\beta$-1,2-Mannosyltransferase } \\
\hline Man $\beta 1-2$ Man-PA & \multicolumn{2}{|c|}{0} \\
\hline $\operatorname{Man} \beta 1-2 \operatorname{Man} \beta 1-2$ Man-PA & \multicolumn{2}{|c|}{0} \\
\hline Man $\beta 1-2 M a n \alpha 1-2 M a n-P A$ & \multicolumn{2}{|c|}{20} \\
\hline $\operatorname{Man} \beta 1-2 \operatorname{Man} \beta 1-2 \operatorname{Man} \beta 1-2 M a n-P A$ & \multicolumn{2}{|c|}{0} \\
\hline Man $\alpha 1-2$ Man $\alpha 1-2 M a n \alpha 1-2 M a n-P A$ & \multicolumn{2}{|c|}{0} \\
\hline $\operatorname{Man} \beta 1-2 M a n \alpha 1-2 M a n \alpha 1-2 M a n \alpha 1-2 M a n-P A$ & \multicolumn{2}{|c|}{29} \\
\hline Man $\beta 1-2$ Man $\alpha 1-3$ Man $\alpha 1-2$ Man $\alpha 1-2$ Man-PA & \multicolumn{2}{|c|}{29} \\
\hline \multirow[t]{3}{*}{ Man $\beta 1$-2Man $\beta 1-2 M a n \alpha 1-2 M a n \alpha 1-2 M a n \alpha 1-2 M a n-P A$} & \multicolumn{2}{|c|}{0} \\
\hline & \multicolumn{2}{|c|}{ C. guilliermondii } \\
\hline & $\beta$-1,2-Mannosyltransferase & $\alpha$-1,6-Mannosyltransferase \\
\hline Man $\alpha 1-3$ Man $\alpha 1-2$ Man-PA & 13 & 149 \\
\hline Man $\alpha 1-2$ Man $\alpha 1-2$ Man $\alpha 1-2$ Man-PA & 0 & 0 \\
\hline Man $\alpha 1-3$ Man $\alpha 1-2$ Man $\alpha 1-2 M a n-P A$ & 1 & 41 \\
\hline Man $\alpha 1-3$ Man $\alpha 1-2$ Man-PA & 52 & $-^{a)}$ \\
\hline \multicolumn{3}{|l|}{$\uparrow 6$} \\
\hline \multicolumn{3}{|l|}{$\operatorname{Man} \alpha 1$} \\
\hline Man $\alpha 1-3$ Man $\alpha 1-2$ Man $\alpha 1-2 M a n \alpha 1-2 M a n-P A$ & 1 & 49 \\
\hline Man $\alpha 1-3$ Man $\alpha 1-3$ Man $\alpha 1-2$ Man $\alpha 1-2$ Man-PA & 6 & 97 \\
\hline Man $\alpha 1-3$ Man $\alpha 1-2$ Man $\alpha 1-2$ Man-PA & 52 & - \\
\hline \multicolumn{3}{|l|}{$\uparrow 6$} \\
\hline \multicolumn{3}{|l|}{$\operatorname{Man} \alpha 1$} \\
\hline Man $\alpha 1-3$ Man $\alpha 1-2$ Man $\alpha 1-2$ Man $\alpha 1-2$ Man-PA & 60 & - \\
\hline \multicolumn{3}{|l|}{$\uparrow 6$} \\
\hline \multicolumn{3}{|l|}{$\operatorname{Man} \alpha 1$} \\
\hline Man $\alpha 1-3$ Man $\alpha 1-3$ Man $\alpha 1-2$ Man $\alpha 1-2$ Man-PA & 48 & - \\
\hline$\uparrow 6$ & & \\
\hline $\operatorname{Man} \alpha 1$ & & \\
\hline
\end{tabular}

a) Not determined.

\section{C. albicans serotype A}

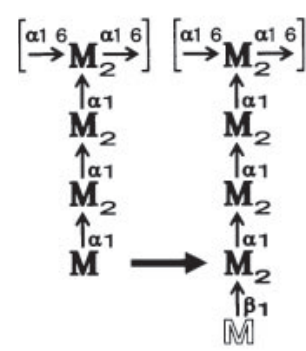

$\beta$-1,2-mannosyltransferase-IA

\section{Iusitaniae}

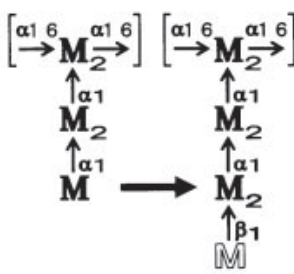

$\beta$-1,2-mannosyltransferase-IB

\section{Citeromyces} matritensis

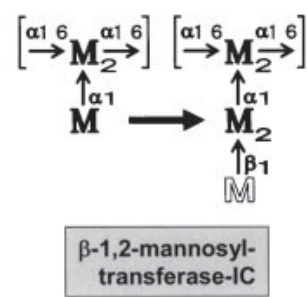

Fig. 8. Hypothetical substrates of $\beta-1,2$-mannosyltransferase I of three Candida species. 


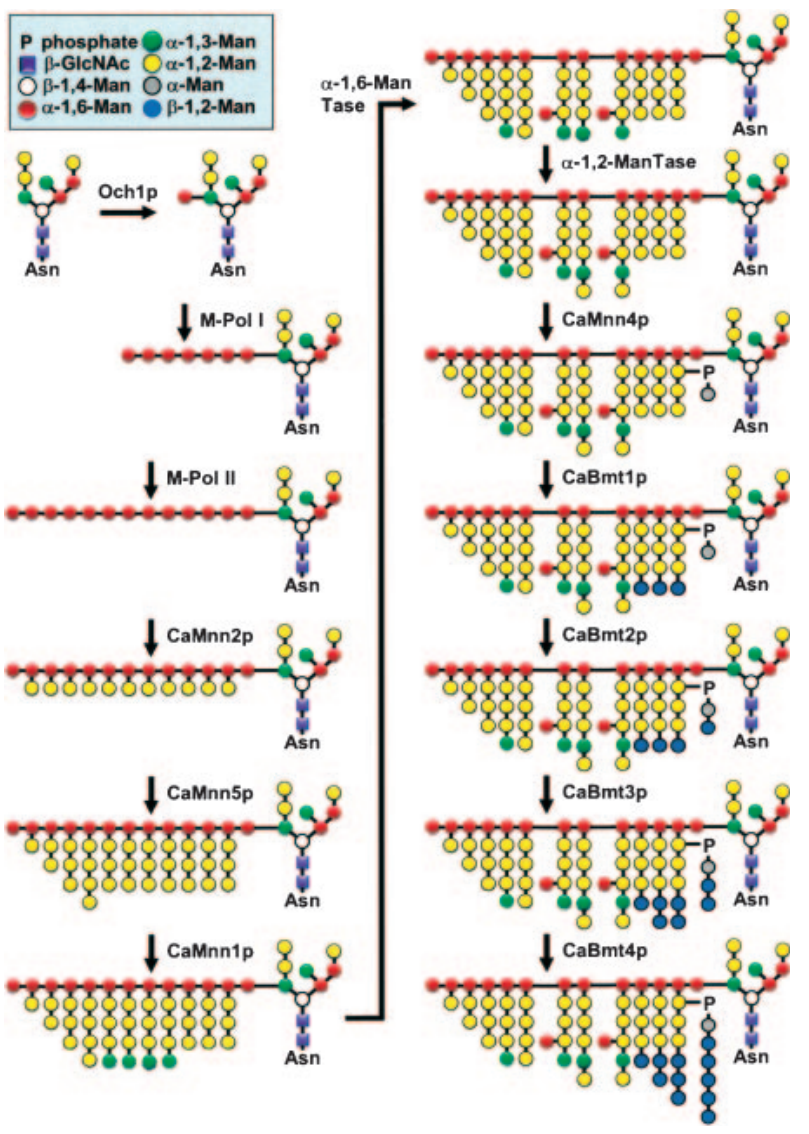

Fig. 9. Biosynthesis pathway of N-linked mannan of C. albicans. The left side of the biosynthesis pathway is similar to that of $S$. cerevisiae and the right side is characteristic of $C$. albicans, the pathway of which involves the introduction of the $\alpha-1,6$ branched mannose units and the $\beta-1,2$-linked mannose units in the side chains.

S. cerevisiae Mnn4p-containing lysine-glutamic acid rich repeats (KKKKEEEE) as a probe and found four new genes encoding $\beta$-1,2-ManTase. Using these sequence data, they subsequently identified nine homologs in $C$. albicans. They performed a deletion study of four genes, CaBMT1-4, and identified the reaction position of these $\beta-1,2$-ManTases in the biosynthesis pathway. ${ }^{56)}$ From the results of these structural and enzymatic analyses, the biosynthesis pathway of the mannan of $C$. albicans was deduced (Fig. 9).

\section{Correlation between pathogenicity and mannan structure of $C$. albicans species}

Adherence of $C$. albicans cells to host receptors is important for the establishment of colonization and initiation of invasion into host tissues. Therefore, the structure of the cell wall mannan has received much attention. It was reported that the factor 6 antigen of $C$. albicans serotype $\mathrm{A}$, which contains a $\beta$-1,2-linked mannose unit at the non-reducing terminal of the $\alpha$-1,2-linked mannooligosaccharide, plays a role in fungal adherence to epithelial cells. ${ }^{57}$ ) The factor 5 antigen, which corresponds to the $\beta-1,2-$ linked mannooligosaccharide, has also been shown to induce tumor necrosis factor (TNF)- $\alpha$ and eicosanoid production through binding to macrophages via galectin-3. ${ }^{58), 59)}$ The $\alpha$-linked oligomannosyl side chains have also been shown to have a strong adhesion activity. ${ }^{60)-62)}$ With an inhibition assay using a monoclonal antibody specific for each synthetic oligosaccharide, Dalle et al. ${ }^{63)}$ demonstrated that $\beta$-1,2- and $\alpha$-1,2-linked mannooligosaccharides participate in the adherence of $C$. albicans cells to enterocytes. The prevention of intestinal colonization by $C$. albicans through the oral administration of synthetic $\beta$-1,2-linked mannooligosaccharides was demonstrated by Dromer et al. ${ }^{64)}$ Moreover, Cutler and coworkers ${ }^{65), 66)}$ demonstrated that the monoclonal antibody against $\beta$-1,2-linked mannooligosaccharides protects against disseminated candidiasis and vaginal infection. Recently, Lee et al. ${ }^{67)}$ showed the effectiveness of a monoclonal antibody against $\beta$-1,2-linked mannooligosaccharides, in combination with fluconazole, against candidiasis.

Och1p, an $\alpha$-1,6-ManTase, is responsible for the initiation of outer chain backbone synthesis. Bates et al. ${ }^{68)}$ showed that the virulence of an och1s null mutant of $C$. albicans was attenuated in a murine model of systemic infection. Bai et al. ${ }^{69)}$ also showed the importance of an $\alpha$-1,2-ManTase responsible for the synthesis of the side chains of the N-linked mannan. They demonstrated that an mnn $5 \Delta$ null mutant of $C$. albicans markedly reduced virulence.

Protein O-mannosyl transferases (Pmtp) participate in the first mannosylation step during the synthesis of O-linked mannooligosaccharides in the mannoprotein. Ernst and coworkers ${ }^{70)-72)}$ showed that $\operatorname{Pmtp}(\mathrm{s})$ were required for growth, antifungal resistance, biofilm formation, hyphal formation, and virulence in $C$. albicans. The addition of further mannose units to the first O-linked mannose unit involves ManTases including Mnt1p and Mnt2p for the transfer of the second and third $\alpha$-1,2-linked mannose units. Synthesis of the O-linked oligomannosyl moiety by Mnt1p and Mnt2p is required for adhesion of $C$. albicans cells to human buccal epithelial cells and to rat vaginal epithelial cells, and for virulence. ${ }^{73), 74)}$ 


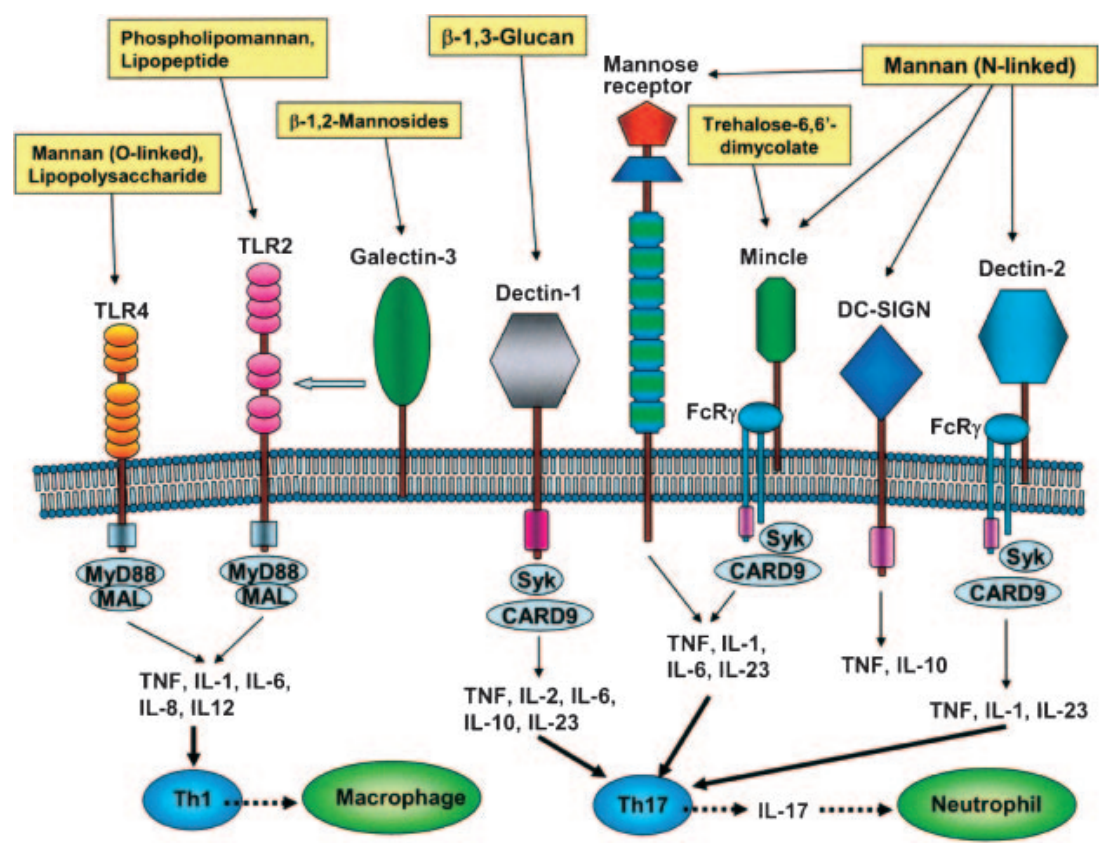

Fig. 10. Pattern recognition receptors sensing C. albicans. The C. albicans mannan induces IL-1 $\beta$ and IL-23 secretion in a Dectin-2dependent manner and induces Th17 cell differentiation. IL-17A from Th17 cells recruits neutrophils to inflammatory sites.

\section{Structural changes in Candida mannan under several growth conditions}

C. albicans are known to be able to grow in two forms: as yeast cells and hyphal cells, a condition called dimorphism that is dependent on many factors such as growth temperature and the presence of serum or N-acetylglucosamine. We demonstrated a decrease in phosphate-bound $\beta$-1,2-linked mannooligosaccharides in the mannan of hyphal cells compared to yeast cells. ${ }^{25), 35), 38)}$ Growth of the cells under acidic conditions at $\mathrm{pH} 2.0^{75), 76)}$ or under high temperature conditions at $37^{\circ} \mathrm{C}^{77), 78)}$ instead of the standard growth temperature $\left(25-28^{\circ} \mathrm{C}\right)$ causes a decrease or disappearance of $\beta-1,2$-linked mannose units in the mannan. Such a change in the epitopes in vitro can also be assumed to take place in patients. Since serological diagnosis for invasive candidiasis is directed at the detection of a specific circulating cell wall antigen or cytoplasmic antigen, the change in antigen profile will directly affect the sensitivity and specificity of diagnosis.

\section{Phospholipomannan}

Poulain and coworkers ${ }^{79)-81)}$ found the existence of a glycolipid on the cell surface of C. albicans, the so-called phospholipomannan, composed of long linear $\beta$-1,2-linked mannooligosaccharides that reach up to 20 units in length, and phytoceramide with a spacer structure: -Man-P-Man-inositol-P-. They showed the involvement of the Toll-like receptor 2 (TLR2) in the phospholipomannan-induced TNF- $\alpha$ production by macrophages, which correlates with activation of the nuclear factor $(\mathrm{NF})-\kappa \mathrm{B} .{ }^{82)}$ Furthermore, they showed that the phospholipomannan promotes survival of phagocytosed Candida cells through activation of macrophage apoptosis by down-regulation of ERK1/2 signal transduction, a decrease in p90 ${ }^{r s k}$ and Bad phosphorylation, and elimination of free Bcl-2. ${ }^{83)}$ Mille et al. ${ }^{84)}$ showed that deletion of a ManTase responsible for the synthesis of phospholipomannan in C. albicans reduced virulence in mouse.

\section{Recognition of Candida cells by innate immunity}

C-type lectin receptors are a family of patternrecognition receptors that recognize the structures of cell-surface polysaccharides. The mannose receptor, Dectin-2, dendritic-cell-specific intercellular adhesion molecule-3 (ICAM-3)-grabbing non-integrin (DCSIGN), and Langerin recognize $\alpha$-mannan and Dectin-1 recognizes $\beta$-1,3-glucan in the fungal cell wall. Some of these receptors are central to the fungal recognition and induction of the innate antifungal immune response. Dectin-2 recognizes high-mannose 
structures $^{85), 86)}$ and induces cytokine production by signaling through an Fc receptor $\gamma$ chain ${ }^{85)}$ and in a Syk-CARD9-NF- $\kappa$ B-dependent manner. ${ }^{87)}$ Although the cytokine-inducing activity of the hyphal cell was much stronger than that of the yeast form, only Dectin-2 is responsible for the induction of cytokines, interleukin (IL)-1 $\beta$, IL-6, IL-23, and TNF. Dectin-2 signaling by Candida mannan preferentially promotes Th17 cell differentiation, and IL-17A from Th17 cells recruits neutrophils to the inflammatory sites and activates both $\mathrm{T}$ and $\mathrm{B}$ cells (Fig. 10). DCSIGN recognizes several endogenous ligands as well as microbial pathogens, including C. albicans, Aspergillus fumigatus, Mycobacterium tuberculosis, some viruses and protozoa via mannose and fucose moieties on the surface of the pathogens. Cambi et $a l^{88)}$ showed that recognition of the N-linked $\alpha$ mannan, but not the O-linked $\alpha$-mannooligosaccharides or phosphate-bound $\beta$-1,2-linked mannooligosaccharides, by DC-SIGN is important for binding and phagocytosis of $C$. albicans by human dendritic cells and production of the proinflammatory cytokine IL-6. Recently, the macrophage-inducible C-type lectin (Mincle) was also found to bind to mannan and Candida cells. ${ }^{89), 90)}$ Intelectin, ${ }^{91)}$ a galactofuranosebinding lectin, also seems to participate in the recognition of many pathogenic fungi, such as Aspergillus fumigatus, ${ }^{92)}$ Trichophyton rubrum, ${ }^{93)}$ Malassezia furfur, ${ }^{94)}$ and Fonsecaea pedrosoi, ${ }^{95)}$ all of which have been found to contain galactofuranose units in their cell wall polysaccharides.

\section{Conclusions}

Epidemiological studies have revealed that emerging Candida species may vary geographically in frequency of isolation. Although the most common non-albicans in the United States is C. glabrata, in Latin America and Asia-Pacific region it is C. parapsilosis and C. tropicalis. It is also known that elevated rates of fluconazole resistance occur among the isolates of C. glabrata, C. krusei, $C$. guilliermondii, C. rugosa, and C. famata. Therefore, it is important to identify the clinical isolates of Candida at the species level and/or by susceptibility testing. The adhesion of Candida to epithelial cells facilitates colonization and can be regarded as the first step in the pathogenesis of Candida infection. In this process cell wall mannooligosaccharide side chains appear to be involved as well as Candida cell-surface hydrophobic proteins, integrin analogs, fimbrial adhesins and lectin-like adhesins with specificity for L-fucose or D-GlcNAc. The increase in invasive candidiasis requires further investigation in order to understand the mechanisms of pathogenesis, the findings of which may provide a new immunitybased therapy or prophylaxis.

\section{Acknowledgements}

The corresponding author, S. Suzuki, expresses his deepest thank to the late Profs., S. Akiya, T. Ukita, and S. Okui, for their excellent guidance.

\section{References}

1) Pfaller, M.A. (1996) Nosocomial candidiasis: emerging species, reservoirs, and modes of transmission. Clin. Infect. Dis. 22, S89-S94.

2) Tsuchiya, T., Fukazawa, Y. and Kawakita, S. (1965) Significance of serological studies on yeast. Mycopathol. Mycol. Appl. 26, 1-15.

3) Tsuchiya, T., Fukazawa, Y., Taguchi, M., Nakase, T. and Shinoda, T. (1974) Serologic aspects on yeast classification. Mycopathol. Mycol. Appl. 53, $77-91$.

4) Tsuchiya, T., Taguchi, S., Fukazawa, Y. and Shinoda, T. (1984) Serological characterization of yeasts as an aid in identification and classification. In Methods in Microbiology (ed. Bergan, T.). Academic Press, New York, 16, pp. 75-126.

5) Fukazawa, Y., Nishikawa, A., Suzuki, M. and Shinoda, T. (1980) Immunochemical basis of the serologic specificity of the yeast: Immunochemical determinants of several antigenic factors of yeasts. In Medical Mycology (ed. Preusser, H.J.) Zbl. Bakt. Suppl. 8. Gustav Fischer Verlag, Stuttgart, New York, pp. 126-136.

6) Hasenclever, H.F. and Mitchell, W.O. (1961) Antigenic studies of Candida. I. Observation of two antigenic groups in Candida albicans. J. Bacteriol. 82, 570-573.

7) Summers, D.F., Grollman, A.P. and Hasenclever, H.F. (1964) Polysaccharide antigens of Candida cell wall. J. Immunol. 92, 491-499.

8) Gorin, P.A.J. and Spencer, J.F.T. (1970) Proton magnetic resonance spectroscopy - an aid in identification and chemotaxonomy of yeasts. Adv. Appl. Microbiol. 13, 25-89.

9) Gorin, P.A.J., Spencer, J.F.T. and Bhattacharjee, S.S. (1969) Structures of yeast mannans containing both $\alpha$ - and $\beta$-linked D-mannopyranose units. Can. J. Chem. 47, 1499-1505.

10) Suzuki, S., Sunayama, H. and Saito, T. (1968) Studies on the antigenic activity of yeasts. I. Analysis of the determinant groups of the mannan of Saccharomyces cerevisiae. Jpn. J. Microbiol. 12, $19-24$.

11) Suzuki, S. and Sunayama, H. (1968) Studies on the antigenic activities of yeasts. II. Isolation and inhibition assay of the oligosaccharides from acetolysate of the mannan of Candida albicans. Jpn. J. Microbiol. 12, 413-422.

12) Sunayama, H. (1970) Studies on the antigenic 
activities of yeasts. IV. Analysis of the antigenic determinant groups of the mannan of Candida albicans serotype A. Jpn. J. Microbiol. 14, 27-39.

13) Sunayama, H. and Suzuki, S. (1970) Studies on the antigenic activities of yeasts. VI. Analysis of the antigenic determinants of the mannan of Candida albicans serotype B-792. Jpn. J. Microbiol. 14, 371-379.

14) Suzuki, M. and Fukazawa, Y. (1982) Immunochemical characterization of Candida albicans cell wall antigens: specific determinant of Candida albicans serotype A mannan. Microbiol. Immunol. 26, 387402.

15) Funayama, M., Nishikawa, A., Shinoda, T. and Fukazawa, Y. (1983) Immunochemical determinant of Candida parapsilosis. Carbohydr. Res. 17, 229-239.

16) Funayama, M., Nishikawa, A., Shinoda, T., Suzuki, M. and Fukazawa, Y. (1984) Antigenic relationship between Candida parapsilosis and Candida albicans serotype B. Microbiol. Immunol. 28, $1359-1371$.

17) Okubo, Y., Ichikawa, T. and Suzuki, S. (1978) Relationship between phosphate content and immunochemical properties of subfractions of bakers' yeast mannan. J. Bacteriol. 136, 63-68.

18) Okubo, Y., Honma, Y. and Suzuki, S. (1979) Relationship between phosphate content and serological activities of the mannans of Candida albicans strains NIH A-207, NIH B-792, and J1012. J. Bacteriol. 137, 677-680.

19) Suzuki, S. (1997) Immunochemical study on mannans of genus Candida. I. Structural investigation of antigenic factors $1,4,5,6,8,9,11,13,13 \mathrm{~b}$ and 34. Curr. Top. Med. Mycol. 8, 57-70.

20) Suzuki, S. (2002) Serological differences among the pathogenic Candida spp. In Candida and Candidiasis (ed. Calderone, R.A.). ASM Press, Washington, D.C., pp. 29-36.

21) Martínez, J.P., Gil, M.L., López-Ribot, J.L. and Chaffin, W.L. (1998) Serologic response to cell wall mannoproteins and proteins of Candida albicans. Clin. Microbiol. Rev. 11, 121-141.

22) Rosenfeld, L. and Ballou, C.E. (1974) Genetic control of yeast mannan structure. Biochemical basis for the transformation of Saccharomyces cerevisiae somatic antigen. J. Biol. Chem. 249, $2319-2321$.

23) Shibata, N., Ichikawa, T., Tojo, M., Takahashi, M., Ito, N., Okubo, Y. and Suzuki, S. (1985) Immunochemical study on the mannans of Candida albicans NIH A-207, NIH B-792, and J-1012 strains prepared by fractional precipitation with cetyltrimethylammonium bromide. Arch. Biochem. Biophys. 243, 338-348.

24) Kobayashi, H., Shibata, N., Nakada, M., Chaki, S., Mizugami, K., Ohkubo, Y. and Suzuki, S. (1990) Structural study of cell wall phosphomannan of Candida albicans NIH B-792 (serotype B) strain, with special reference to ${ }^{1} \mathrm{H}$ and ${ }^{13} \mathrm{C}$ NMR analyses of acid-labile oligomannosyl units. Arch. Biochem. Biophys. 278, 195-204.
25) Shibata, N., Kobayashi, H., Tojo, M. and Suzuki, S. (1986) Characterization of phosphomannan-protein complexes isolated from viable cells of yeast and mycelial forms of Candida albicans NIH B-792 strain by the action of Zymolyase-100T. Arch. Biochem. Biophys. 251, 697-708.

26) Shibata, N., Arai, M., Haga, E., Kikuchi, T., Najima, M., Satoh, T., Kobayashi, H. and Suzuki, S. (1992) Structural identification of an epitope of antigenic factor 5 in mannans of Candida albicans NIH B792 (serotype B) and J-1012 (serotype A) as $\beta-1,2$ linked oligomannosyl units. Infect. Immun. 60, 4100-4110.

27) Shibata, N., Hisamichi, K., Kikuchi, T., Kobayashi, H., Okawa, Y. and Suzuki, S. (1992) Sequential nuclear magnetic resonance assignment of $\beta-1,2-$ linked mannooligosaccharides isolated from the phosphomannan of the pathogenic yeast Candida albicans NIH B-792 strain. Biochemistry 31, 56805686 .

28) Shibata, N., Hisamichi, K., Kobayashi, H. and Suzuki, S. (1993) Complete assignment of ${ }^{1} \mathrm{H}$ and ${ }^{13} \mathrm{C}$ nuclear magnetic resonance chemical shifts of $\beta$-1,2-linked mannooligosaccharides isolated from the phosphomannan of the pathogenic yeast Candida albicans NIH B-792 strain. Arch. Biochem. Biophys. 302, 113-117.

29) Faille, C., Wieruszeski, J.M., Lepage, G., Michalski, J.C., Poulain, D. and Strecker, G. (1991) ${ }^{1} \mathrm{H}-\mathrm{NMR}$ spectroscopy of manno-oligosaccharides of the $\beta$ 1,2-linked series released from the phosphopeptidomannan of Candida albicans VW-32 (serotype A). Biochem. Biophys. Res. Commun. 181, 12511258 .

30) Faille, C., Wieruszeski, J.M., Michalski, J.C., Poulain, D. and Strecker, G. (1992) Complete ${ }^{1} \mathrm{H}$ - and ${ }^{13} \mathrm{C}$-resonance assignments for D-mannooligosaccharides of the $\beta$-D- $(1 \rightarrow 2)$-linked series released from the phosphopeptidomannan of Candida albicans VW-32 (serotype A). Carbohydr. Res. 236, 17-27.

31) Nitz, M., Ling, C.-C., Otter, A., Cutler, J.E. and Bundle, D.R. (2002) The unique solution structure and immunochemistry of the Candida albicans $\beta-1,2$-mannopyranan cell wall antigens. J. Biol. Chem. 277, 3440-3446.

32) Shibata, N. and Okawa, Y. (2010) Conformational analysis of $\beta$-1,2-linked mannobiose to mannoheptaose, specific antigen of pathogenic yeast Candida albicans. Chem. Pharm. Bull. 58, 1386-1390.

33) Kocourek, J. and Ballou, C.E. (1969) Method for fingerprinting yeast cell wall mannans. J. Bacteriol. 100, 1175-1181.

34) Kobayashi, H., Shibata, N. and Suzuki, S. (1986) Acetolysis of Pichia pastoris IFO 0948 strain mannan containing $\alpha-1,2$ and $\beta-1,2$ linkages using acetolysis medium of low sulfuric acid concentration. Arch. Biochem. Biophys. 245, 494-503.

35) Shibata, N., Fukasawa, S., Kobayashi, H., Tojo, M., Yonezu, T., Ambo, A., Ohkubo, Y. and Suzuki, S. (1989) Structural analysis of phospho-D-mannanprotein complexes isolated from yeast and mold 
form cells of Candida albicans NIH A-207 serotype A strain. Carbohydr. Res. 187, 239-253.

36) Kobayashi, H., Shibata, N., Mitobe, H., Ohkubo, Y. and Suzuki, S. (1989) Structural study of phosphomannan of yeast-form cells of Candida albicans J-1012 strain with special reference to application of mild acetolysis. Arch. Biochem. Biophys. 272, 364-375.

37) Kobayashi, H., Shibata, N., Osaka, T., Miyagawa, Y., Ohkubo, Y. and Suzuki, S. (1992) Structural study of cell wall mannan of a Candida albicans (serotype A) strain. Phytochemistry 31, 11471153.

38) Shibata, N., Suzuki, A., Kobayashi, H. and Okawa, Y. (2007) Chemical structure of the cell-wall mannan of Candida albicans serotype A and its difference in yeast and hyphal forms. Biochem. J. 404, 365-372.

39) Kobayashi, H., Shibata, N. and Suzuki, S. (1992) Evidence for oligomannosyl units containing both $\beta-1,2$ and $\alpha-1,2$ linkages as a serotype A-specific epitope(s) in mannan of Candida albicans. Infect. Immun. 60, 2106-2109.

40) Kobayashi, H., Matsuda, K., Ikeda, T., Suzuki, M., Takahashi, S., Suzuki, A., Shibata, N. and Suzuki, S. (1994) Structures of cell wall mannans of pathogenic Candida tropicalis IFO 0199 and IFO 1647 yeast strains. Infect. Immun. 62, 615-622.

41) Shibata, N., Kobayashi, H., Okawa, Y. and Suzuki, S. (2003) Existence of novel $\beta-1,2$ linkage-containing side chain in the mannan of Candida lusitaniae, antigenically related to Candida albicans serotype A. Eur. J. Biochem. 270, 2565-2575.

42) Kobayashi, H., Mitobe, H., Takahashi, K., Yamamoto, T., Shibata, N. and Suzuki, S. (1992) Structural study of a cell wall mannan-protein complex of the pathogenic yeast Candida glabrata IFO 0622 strain. Arch. Biochem. Biophys. 294, 662-669.

43) Shibata, N., Akagi, R., Hosoya, T., Kawahara, K., Suzuki, A., Ikuta, K., Kobayashi, H., Hisamichi, K., Okawa, Y. and Suzuki, S. (1996) Existence of novel branched side chains containing $\beta-1,2$ and $\alpha-1,6$ linkages corresponding to antigenic factor 9 in the mannan of Candida guilliermondii. J. Biol. Chem. 271, 9259-9266.

44) Shibata, N., Onozawa, M., Tadano, N., Hinosawa, Y., Suzuki, A., Ikuta, K., Kobayashi, H., Suzuki, S. and Okawa, Y. (1996) Structure and antigenicity of the mannans of Candida famata and Candida saitoana: Comperative study of the mannan of Candida guilliermondii. Arch. Biochem. Biophys. 336, 49-58.

45) Reiss, E., Patterson, D.G., Yert, L.W., Holler, J.S. and Ibrahim, B.K. (1981) Structural analysis of mannans from Candida albicans serotypes A and B and from Torulopsis glabrata by methylation gas chromatography mass spectrometry and exo- $\alpha$ mannanase. Biomed. Mass Spectrom. 8, 252-255.

46) Kogan, G., Pavliak, V. and Masler, L. (1988) Structural studies of mannans from the cell walls of the pathogenic yeasts Candida albicans serotypes A and B and Candida parapsilosis. Carbohydr. Res. 172, 243-253.

47) Shibata, N., Ikuta, K., Imai, T., Satoh, Y., Satoh, R., Suzuki, A., Kojima, C., Kobayashi, H., Hisamichi, K. and Suzuki, S. (1995) Existence of branched side chains in the cell wall mannan of pathogenic yeast, Candida albicans: Structure-antigenicity relationship between the cell wall mannans of Candida albicans and Candida parapsilosis. J. Biol. Chem. 270, 1113-1122.

48) Shibata, N., Senbongi, N., Hosoya, T., Kawahara, K., Akagi, R., Suzuki, A., Kobayashi, H., Suzuki, S. and Okawa, Y. (1997) Demonstration of the presence of $\alpha$-1,6-branched side chains in the mannan of Candida stellatoidea. Eur. J. Biochem. 246, 477-485.

49) Zhang, W.J. and Ballou, C.E. (1981) Saccharomyces kluyveri cell wall mannoprotein. Structures of the O- and N-linked carbohydrate components. J. Biol. Chem. 256, 10073-10079.

50) Shibata, N., Kojima, C., Satoh, Y., Satoh, R., Suzuki, A., Kobayashi, H. and Suzuki, S. (1993) Structural study of a cell-wall mannan of Saccharomyces kluyveri IFO 1685 strain: Presence of a branched side chain and $\beta$-1,2-linkage. Eur. J. Biochem. 217, 1-12.

51) Suzuki, A., Shibata, N., Suzuki, M., Saitoh, F., Takata, Y., Oshie, A., Oyamada, H., Kobayashi, H., Suzuki, S. and Okawa, Y. (1996) Characterization of $\alpha$-1,6-mannosyltransferase responsible for the synthesis of branched side chains in Candida albicans mannan. Eur. J. Biochem. 240, $37-44$.

52) Suzuki, A., Takata, Y., Oshie, A., Tezuka, A., Shibata, N., Kobayashi, H., Okawa, Y. and Suzuki, S. (1995) Detection of $\beta-1,2$-mannosyltransferase in Candida albicans cells. FEBS Lett. 373, 275-279.

53) Kobayashi, H., Shibata, N., Yonezu, T. and Suzuki, S. (1987) Structural study of phosphomannanprotein complex of Citeromyces matritensis containing $\beta-1,2$ linkage. Arch. Biochem. Biophys. 256, 381-396.

54) Suzuki, A., Shibata, N., Suzuki, M., Saitoh, F., Oyamada, H., Kobayashi, H., Suzuki, S. and Okawa, Y. (1997) Characterization of $\beta-1,2$-mannosyltransferase in Candida guilliermondii, and its utilization in the synthesis of novel oligosaccharides. J. Biol. Chem. 272, 16822-16828.

55) Mille, C., Bobrowicz, P., Trinel, P.A., Li, H., Maes, E., Guerardel, Y., Fradin, C., Martínez-Esparza, M., Davidson, R.C., Janbon, G., Poulain, D. and Wildt, S. (2008) Identification of a new family of genes involved in $\beta$-1,2-mannosylation of glycans in Pichia pastoris and Candida albicans. J. Biol. Chem. 283, 9724-9736.

56) Maes, E., Mille, C., Trivelli, X., Janbon, G., Poulain, D. and Guérardel, Y. (2009) Molecular phenotyping of mannosyltransferases-deficient Candida albicans cells by high-resolution magic angle spinning NMR. J. Biochem. 145, 413-419.

57) Miyakawa, Y., Kuribayashi, T., Kagaya, K., Suzuki, 
M., Nakase, T. and Fukazawa, Y. (1992) Role of specific determinants in mannan of Candida albicans serotype $\mathrm{A}$ in adherence to human buccal epithelial cells. Infect. Immun. 60, 2493-2499.

58) Fradin, C., Jouault, T., Mallet, A., Mallet, J.M., Camus, D., Sinaÿ, P. and Poulain, D. (1996) $\beta-1,2-$ Linked oligomannosides inhibit Candida albicans binding to murine macrophage. J. Leukoc. Biol. 60, 81-87.

59) Fradin, C., Poulain, D. and Jouault, T. (2000) $\beta-1,2-$ Linked oligomannosides from Candida albicans bind to a 32-kilodalton macrophage membrane protein homologous to the mammalian lectin galectin-3. Infect. Immun. 68, 4391-4398.

60) Kanbe, T., Han, Y., Redgrave, B., Riesselman, M.H. and Cutler, J.E. (1993) Evidence that mannans of Candida albicans are responsible for adherence of yeast forms to spleen and lymph node tissue. Infect. Immun. 61, 2578-2584.

61) Kanbe, T. and Cutler, J.E. (1994) Evidence for adhesin activity in the acid-stable moiety of the phosphomannoprotein cell wall complex of Candida albicans. Infect. Immun. 62, 1662-1668.

62) Kanbe, T. and Cutler, J.E. (1998) Minimum chemical requirements for adhesin activity of the acidstable part of Candida albicans cell wall phosphomannoprotein complex. Infect. Immun. 66, 58125818.

63) Dalle, F., Jouault, T., Trinel, P.A., Esnault, J., Mallet, J.M., d'Athis, P., Poulain, D. and Bonnin, A. (2003) $\beta$-1,2- and $\alpha$-1,2-Linked oligomannosides mediate adherence of Candida albicans blastospores to human enterocytes in vitro. Infect. Immun. 71, 7061-7068.

64) Dromer, F., Chevalier, R., Sendid, B., Improvisi, L., Jouault, T., Robert, R., Mallet, J.M. and Poulain, D. (2002) Synthetic analogues of $\beta-1,2$ oligomannosides prevent intestinal colonization by the pathogenic yeast Candida albicans. Antimicrob. Agents Chemother. 46, 3869-3876.

65) Han, Y., Morrison, R.P. and Cutler, J.E. (1998) A vaccine and monoclonal antibodies that enhance mouse resistance to Candida albicans vaginal infection. Infect. Immun. 66, 5771-5776.

66) Han, Y., Riesselman, M.H. and Cutler, J.E. (2000) Protection against candidiasis by an immunoglobulin G3 (IgG3) monoclonal antibody specific for the same mannotriose as an IgM protective antibody. Infect. Immun. 68, 1649-1654.

67) Lee, J.H., Jang, E.C. and Han, Y. (2011) Combination immunotherapy of MAb B6.1 with fluconazole augments therapeutic effect to disseminated candidiasis. Arch. Pharm. Res. 34, 399-405.

68) Bates, S., Hughes, H.B., Munro, C.A., Thomas, W.P., MacCallum, D.M., Bertram, G., Atrih, A., Ferguson, M.A., Brown, A.J., Odds, F.C. and Gow, N.A. (2006) Outer chain N-glycans are required for cell wall integrity and virulence of Candida albicans. J. Biol. Chem. 281, 90-98.

69) Bai, C., Xu, X.L., Chan, F.Y., Lee, R.T. and Wang, Y. (2006) MNN5 encodes an iron-regulated $\alpha-1,2$ mannosyltransferase important for protein glyco- sylation, cell wall integrity, morphogenesis, and virulence in Candida albicans. Eukaryot. Cell 5, 238-247.

70) Timpel, C., Zink, S., Strahl-Bolsinger, S., Schröppel, K. and Ernst, J. (2000) Morphogenesis, adhesive properties, and antifungal resistance depend on the Pmt6 protein mannosyltransferase in the fungal pathogen Candida albicans. J. Bacteriol. 182, 3063-3071.

71) Prill, S.K., Klinkert, B., Timpel, C., Gale, C.A., Schröppel, K. and Ernst, J.F. (2005) PMT family of Candida albicans: five protein mannosyltransferase isoforms affect growth, morphogenesis and antifungal resistance. Mol. Microbiol. 55, 546-560.

72) Peltroche-Llacsahuanga, H., Goyard, S., d'Enfert, C., Prill, S.K. and Ernst, J.F. (2006) Protein $O$-mannosyltransferase isoforms regulate biofilm formation in Candida albicans. Antimicrob. Agents Chemother. 50, 3488-3491.

73) Buurman, E.T., Westwater, C., Hube, B., Brown, A.J., Odds, F.C. and Gow, N.A. (1998) Molecular analysis of CaMnt1p, a mannosyl transferase important for adhesion and virulence of Candida albicans. Proc. Natl. Acad. Sci. U.S.A. 95, 76707675 .

74) Munro, C.A., Bates, S., Buurman, E.T., Hughes, H.B., Maccallum, D.M., Bertram, G., Atrih, A., Ferguson, M.A., Bain, J.M., Brand, A., Hamilton, S., Westwater, C., Thomson, L.M., Brown, A.J., Odds, F.C. and Gow, N.A. (2005) Mnt1p and Mnt2p of Candida albicans are partially redundant $\alpha$-1,2-mannosyltransferases that participate in $O$ linked mannosylation and are required for adhesion and virulence. J. Biol. Chem. 280, 1051-1060.

75) Kobayashi, H., Giummelly, P., Takahashi, S., Ishida, M., Sato, J., Takaku, M., Nishidate, Y., Shibata, N., Okawa, Y. and Suzuki, S. (1991) Candida albicans serotype A strains grow in yeast extractadded sabouraud medium at $\mathrm{pH} 2.0$, elaborating mannans without $\beta-1,2$ linkage and phosphate group. Biochem. Biophys. Res. Commun. 175, 1003-1009.

76) Kobayashi, H., Takahashi, S., Shibata, N., Miyauchi, M., Ishida, M., Sato, J., Maeda, K. and Suzuki, S. (1994) Structural modification of cell wall mannans of Candida albicans serotype A strains grown in yeast extract-sabouraud liquid medium under acid conditions. Infect. Immun. 62, 968-973.

77) Okawa, Y., Takahata, T., Kawamata, M., Miyauchi, M., Shibata, N., Suzuki, A., Kobayashi, H. and Suzuki, S. (1994) Temperature-dependent change of serological specificity of Candida albicans NIH A-207 cells cultured in yeast extract-added Sabouraud liquid medium: disappearance of surface antigenic factors 4,5 , and 6 at high temperature. FEBS Lett. 345, 167-171.

78) Okawa, Y., Goto, K., Nemoto, S., Akashi, M., Sugawara, C., Hanzawa, M., Kawamata, M., Takahata, T., Shibata, N., Kobayashi, H. and Suzuki, S. (1996) Antigenicity of cell wall mannans of Candida albicans NIH B-792 (serotype B) strain cells cultured at high temperature in yeast extract- 
containing Sabouraud liquid medium. Clin. Diagn. Lab. Immunol. 3, 331-336.

79) Trinel, P.A., Borg-von-Zepelin, M., Lepage, G., Jouault, T., Mackenzie, D. and Poulain, D. (1993) Isolation and preliminary characterization of the 14- to 18-kilodalton Candida albicans antigen as a phospholipomannan containing $\beta$ 1,2-linked oligomannosides. Infect. Immun. 61, 4398-4405.

80) Trinel, P.A., Plancke, Y., Gerold, P., Jouault, T., Delplace, F., Schwarz, R.T., Strecker, G. and Poulain, D. (1999) The Candida albicans phospholipomannan is a family of glycolipids presenting phosphoinositolmannosides with long linear chains of $\beta$-1,2-linked mannose units. J. Biol. Chem. 274, 30520-30526.

81) Trinel, P.A., Maes, E., Zanetta, J.P., Delplace, F., Coddeville, B., Jouault, T., Strecker, G. and Poulain, D. (2002) Candida albicans phospholipomannan, a new member of the fungal mannose inositol phosphoceramide family. J. Biol. Chem. 277, 37260-37271.

82) Jouault, T., Ibata-Ombetta, S., Takeuchi, O., Trinel, P.A., Sacchetti, P., Lefebvre, P., Akira, S. and Poulain, D. (2003) Candida albicans phospholipomannan is sensed through toll-like receptors. J. Infect. Dis. 188, 165-172.

83) Ibata-Ombetta, S., Idziorek, T., Trinel, P.A., Poulain, D. and Jouault, T. (2003) Candida albicans phospholipomannan promotes survival of phagocytosed yeasts through modulation of bad phosphorylation and macrophage apoptosis. J. Biol. Chem. 278, 13086-13093.

84) Mille, C., Janbon, G., Delplace, F., Ibata-Ombetta, S., Gaillardin, C., Strecker, G., Jouault, T., Trinel, P.A. and Poulain, D. (2004) Inactivation of CaMIT1 inhibits Candida albicans phospholipomannan $\beta$-mannosylation, reduces virulence, and alters cell wall protein $\beta$-mannosylation. J. Biol. Chem. 279, 47952-47960.

85) Sato, K., Yang, X.L., Yudate, T., Chung, J.S., Wu, J., Luby-Phelps, K., Kimberly, R.P., Underhill, D. Cruz, P.D. Jr. and Ariizumi, K. (2006) Dectin-2 is a pattern recognition receptor for fungi that couples with the Fc receptor gamma chain to induce innate immune responses. J. Biol. Chem. 281, 38854-38866.

86) McGreal, E.P., Rosas, M., Brown, G.D., Zamze, S., Wong, S.Y., Gordon, S., Martinez-Pomares, L. and Taylor, P.R. (2006) The carbohydrate-recognition domain of Dectin-2 is a C-type lectin with specificity for high mannose. Glycobiology $\mathbf{1 6}$, 422-430.

87) Saijo, S., Ikeda, S., Yamabe, K., Kakuta, S., Ishigame, H., Akitsu, A., Fujikado, N., Kusaka, T., Kubo, S., Chung, S.H., Komatsu, R., Miura, N., Adachi, Y., Ohno, N., Shibuya, K., Yamamoto,
N., Kawakami, K., Yamasaki, S., Saito, T., Akira, S. and Iwakura, Y. (2010) Dectin-2 recognition of $\alpha$-mannans and induction of Th17 cell differentiation is essential for host defense against Candida albicans. Immunity 32, 681-691.

88) Cambi, A., Netea, M.G., Mora-Montes, H.M., Gow, N.A., Hato, S.V., Lowman, D.W., Kullberg, B.J., Torensma, R., Williams, D.L. and Figdor, C.G. (2008) Dendritic cell interaction with Candida albicans critically depends on $N$-linked mannan. J. Biol. Chem. 283, 20590-20599.

89) Wells, C.A., Salvage-Jones, J.A., Li, X., Hitchens, K., Butcher, S., Murray, R.Z., Beckhouse, A.G., Lo, Y.L., Manzanero, S., Cobbold, C., Schroder, K., Ma, B., Orr, S., Stewart, L., Lebus, D., Sobieszczuk, P., Hume, D.A., Stow, J., Blanchard, H. and Ashman, R.B. (2008) The macrophage-inducible C-type lectin, mincle, is an essential component of the innate immune response to Candida albicans. J. Immunol. 180, 7404-7413.

90) Bugarcic, A., Hitchens, K., Beckhouse, A.G., Wells, C.A., Ashman, R.B. and Blanchard, H. (2008) Human and mouse macrophage-inducible C-type lectin (Mincle) bind Candida albicans. Glycobiology 18, 679-685.

91) Tsuji, S., Uehori, J., Matsumoto, M., Suzuki, Y., Matsuhisa, A., Toyoshima, K. and Seya, T. (2001) Human intelectin is a novel soluble lectin that recognizes galactofuranose in carbohydrate chains of bacterial cell wall. J. Biol. Chem. 276, 2345623463.

92) Latgé, J.P., Kobayashi, H., Debeaupuis, J.P., Diaquin, M., Sarfati, J., Wieruszeski, J.M., Parra, E., Bouchara, J.P. and Fournet, B. (1994) Chemical and immunological characterization of the extracellular galactomannan of Aspergillus fumigatus. Infect. Immun. 62, 5424-5433.

93) Ikuta, K., Shibata, N., Blake, J.S., Dahl, M.V., Nelson, R.D., Kobayashi, H., Hisamichi, K., Suzuki, S. and Okawa, Y. (1997) NMR study of the galactomannans of Trichophyton mentagrophytes and Trichophyton rubrum. Biochem. J. 323, 297-305.

94) Shibata, N., Saitoh, T., Tadokoro, Y. and Okawa, Y. (2009) The cell wall galactomannan antigen from Malassezia furfur and Malassezia pachydermatis contains $\beta$-1,6-linked linear galactofuranosyl units and its detection has diagnostic potential. Microbiology 155, 3420-3429.

95) Shibata, N. and Okawa, Y. (2011) Chemical structure of $\beta$-galactofuranose-containing polysaccharide and $O$-linked oligosaccharides obtained from the cell wall of pathogenic dematiaceous fungus Fonsecaea pedrosoi. Glycobiology 21, 69-81.

(Received Dec. 28, 2011; accepted Mar. 30, 2012) 


\section{Profile}

Nobuyuki Shibata was born in 1956 in Tochigi, Japan. He received his Ph.D. in 1989 from Tohoku College of Pharmacy (presently, Tohoku Pharmaceutical University) under the supervision of Prof. Shigeo Suzuki. He became an Assistant Professor at Tohoku College of Pharmacy in 1981, and was a postdoctoral fellow at the University of Minnesota with Prof. Robert D. Nelson in 1989-1990. He was promoted to Associate Professor in 2000 and then to Professor in 2011 at Tohoku Pharmaceutical University. His research interests are in the fields of carbohydrate chemistry of the cell wall polysaccharide of pathogenic fungi and its immunochemistry. He was awarded the Pharmaceutical Society of Japan Tohoku Branch Award for Young Scientists in 1991.

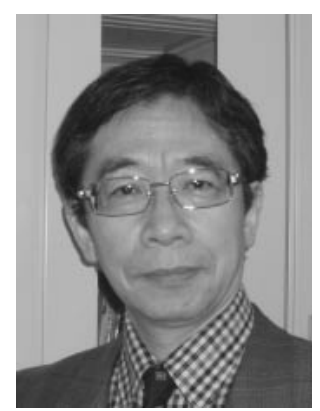

\section{Profile}

Hidemitsu Kobayashi was born in 1961 in Osaka, Japan. He started his research career in 1984 with studies on the structural characterization of antigenic polysaccharides obtained from pathogenic eucaryotic microbe, mainly genus Candida, after graduating from the Tohoku Pharmaceutical University, Sendai, Japan. He was able to give the doctor's degree of pharmacology according to the achievements of the structural study of Candia cell wall mannan in 1991. From 1992 to 1993, he was on the register in Institut Pasteur, Paris, France, as a postdoctoral fellow, and engaged in research of the genus Aspergillus circulating antigen in the human body by instruction of Dr. Jean-Paul Latge. Then he moved to the Department of Microbiology, Faculty of Pharmaceutical Science, Nagasaki International University, Sasebo, Japan, as a professor in 2004. He

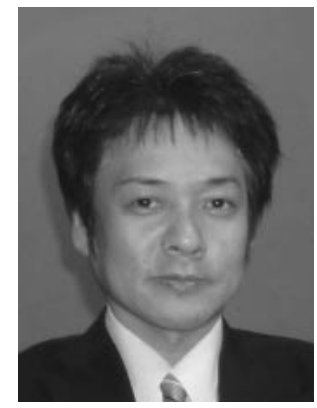
started to study genus Cordyceps, a group of fungi parasitic on viable insects in 2008. These microorganisms are called Toh-Chu-Kaso, which has been used as a drug for longevity in China. Recently, he discovered some low molecular compounds with strong antitumor activity from the Toh-Chu-Kaso, and the research is still continued.

\section{Profile}

Shigeo Suzuki was born in Sendai at 1929. He graduated from Tohoku College of Pharmacy (presently, Tohoku Pharmaceutical University) in 1950. He started his carbohydrate research at 1951 in the Department of Hygienic and Forensic Chemistry, Faculty of Pharmaceutical Sciences at the University of Tokyo as a researcher. Prof. S. Akiya and Assoc. Prof. S. Okui (later, Prof. of Tohoku University) of this department were conducting a work, "Studies on the degradation process of sugars". He participated in the publication of 3 papers of this series at 1952. After publishing 2 carbohydraterelating papers, Prof. Akiya suggested to start a research on sugar-amino acid conjugates. He returned to the Department of Hygienic Chemistry, Tohoku College of Pharmacy at 1958, and this work was continued Prof. T. Ukita, the successor of

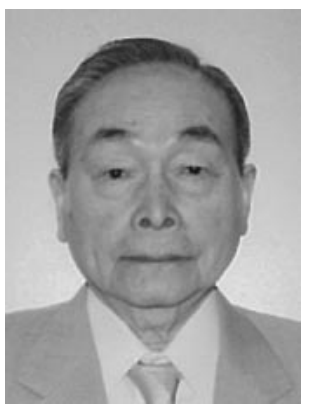
Prof. Akiya, as co-author. At 1961, He was awarded with Ph.D. degree of the University of Tokyo. In 1965, He elevated to the professor of Second Department of Hygienic Chemistry, and started a series of immunochemical investigation of Candida mannan as described in the text. He was honored with the following prizes: 1 . The Japanese Society for Medical Mycology Prize at 1992. 2. The International Society for Human and Animal Mycology Prize at 1997. 3. Naito Memorial Scientific Research Foundation Grant at 1997. He is the honorary members of the following societies: 1 . The Japanese Society for Carbohydrate Research. 2. The Japanese Society of Medical Mycology. 3. The Japanese Society for Chitin.Chitosan Research. 